\title{
Erratum to: An optimizing pipeline stall reduction algorithm for power and performance on multi- core CPUs
}

Vijayalakshmi Saravanan ${ }^{1 *}$, Alagan Anpalagan ${ }^{1}$, Kothari Dwarkadas Pralhaddas ${ }^{2}$ and Isaac Woungang ${ }^{1}$

\author{
* Correspondence: vsaravan@rnet. \\ ryerson.ca \\ ${ }^{1}$ WINCORE Lab, Ryerson University,
} Toronto, Canada

\section{Erratum}

In the original published version of this article [1], the third co-author's name Kothari Dwarkadas Pralhaddas appears twice, and the name of the second co-author Alagan Anpalagan is missing. The correct author list is as follows:

Vijayalakshmi Saravanan, Alagan Anpalagan, Kothari Dwarkadas Pralhaddas and Isaac Woungang

The publisher apologies for this error introduced during publication of this article.

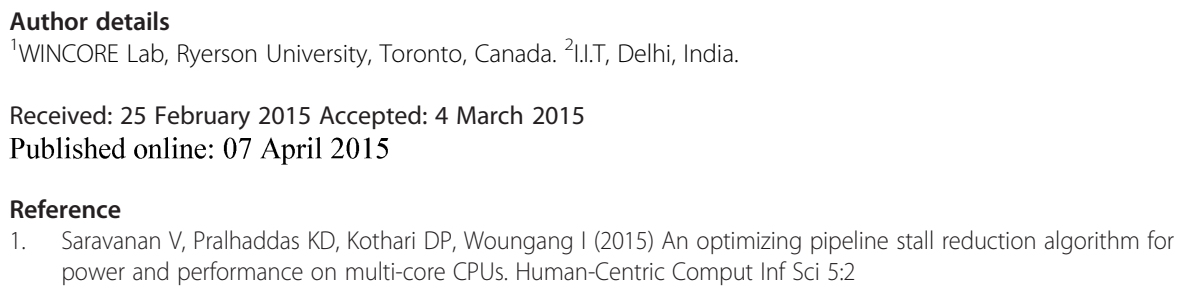

1. Saravanan V, Pralhaddas KD, Kothari DP, Woungang I (2015) An optimizing pipeline stall reduction algorithm for power and performance on multi-core CPUs. Human-Centric Comput Inf Sci 5:2

Submit your manuscript to a SpringerOpen ${ }^{\circ}$ journal and benefit from:

- Convenient online submission

- Rigorous peer review

- Immediate publication on acceptance

- Open access: articles freely available online

- High visibility within the field

- Retaining the copyright to your article

Submit your next manuscript at $>$ springeropen.com 